\title{
Urinary bladder lipoma: an illustrative case
}

\author{
Miguel Paniagua ${ }^{1 *}$, Verónica Parra $^{2}$, Enrique De Miguel ${ }^{1}$ \\ 1. Department of Radiology, Hospital General Universitario Gregorio Marañón, Madrid, Spain \\ 2. Department of Anatomical Pathology Radiology, Hospital General Universitario Gregorio Marañón, Madrid, Spain \\ * Correspondence: Miguel Paniagua González, Department of Radiology, Hospital General Universitario Gregorio Marañón, Calle del \\ Dr. Esquerdo, $n^{\circ} 46,28007$, Madrid, Spain \\ (入 m.paniagua.gonzalez@gmail.com)
}

Radiology Case. 2020 Jun; 14(6):15-21 :: $\quad$ DOI: 10.3941 jrcr.v14i6.3887

\begin{abstract}
Urinary bladder lipomas are rare neoplasms. Therefore, very few of them have been reported in the literature. We present a case that illustrates the typical features that allow radiologists to diagnose this entity: a solid lesion that arises from the urinary bladder wall, showing an endophytic growth and homogeneous hypoattenuation. After its surgical resection, the diagnosis was confirmed by anatomo-pathological analysis. In the discussion we describe other neoplasms that should also be considered when a submucosal bladder neoplasm is detected on computed tomography or other imaging techniques.
\end{abstract}

\section{CASE REPORT}

\section{CASE REPORT}

The patient was a 63-year-old male, former smoker, who had been referred to the urology service with post-micturition dripping.

Urine analytic was perfectly normal, without microscopic haematuria or any signs of infection. Prostate-specific antigen was 1.31 (normal level).

The first diagnostic approach was an urinary ultrasonography. During the exploration, a solid nodule (approximately $1.3 \mathrm{~cm}$ long) was found adjacent to the right bladder wall. It seemed to be an intravesical lesion, which did not change its position after the patient was asked to mobilize (Figure 1).

Even though a lesion like this one could correspond to almost any entity arising from the urinary bladder wall urothelial carcinoma among them-, it showed an echogenicity higher than expected, similar to the fat around the bladder. In fact, the radiologist who managed the exploration proposed that it could even be an extravesical lesion pushing the wall towards inner bladder.

This finding led the urologists to carry out a cystoscopy in order to directly excise the lesion or at least biopsy it. Nevertheless, during the exploration the bladder mucosa seemed to be absolutely intact, covering the lesion without any suspicion of malignancy (a sign that typically occurs when an extravesical mass deforms the bladder wall without infiltrating or penetrating it).

Therefore, an abdominal CT was performed, including non-enhanced phase, venous phase and excretory phase, following the usual diagnostic protocol for the urinary tract lesions. The study revealed the presence of a purely intravesical nodule arising from the right-upper wall of the urinary bladder, perfectly demonstrated at the multiplanar reconstructions. The lesion was homogeneous, with smooth margins, showing attenuation values similar to the peritoneal fat or the subcutaneous cellular tissue (around -101 Hounsfield Units). It did not enhance after the administration of iodinated contrast previous to the venous phase (Figures 2-3-4). 
Assuming the lesion probably corresponded to a lipomatous neoplasm, a surgical resection of the tumour was needed, especially considering that the CT also revealed the presence of some hairline-thin septa inside the lesion (a feature that may be seen in many benign lipomas, but also in some well-differentiated malignant liposarcomas) (Figure 5).

Thus, it was indispensable to carry out an anatomopathological analysis of the tumour, not only to confirm the imaging diagnostic presumption, but also to make sure that the lesion did not show any features of malignancy (in which case it would be necessary a different managing and further followup).

A new cystoscopy was performed, in order to excise the full tumour. The surgical bed was locally treated with homeostasis. The procedure was performed successfully without any complication.

The histological examination described the following findings: Macroscopically, the specimen looked as an adipose brown-coloured fragment. Microscopically, the lesion looked as a well-defined submucosal nodule mostly composed of mature adipocytes without atypia or mitosis (Figure 6). These features were compatible with a submucosal bladder lipoma, with no malignant behaviour.

Three months after the resection, another urinary ultrasound was performed, revealing no findings inside the bladder.

\section{DISCUSSION}

\section{Etiology \& Demographics:}

Primary urinary bladder tumours represent approximately $2 \%-6 \%$ of all neoplasms. They are subdivided in epithelial tumours $(95 \%)$ and submucous/mesenchymal-originated tumours (5\%). Among epithelial neoplasms, the most frequent is the urothelial carcinoma (reaching $90 \%$ of the cases), followed by squamous cell carcinoma (2-8\%) and adenocarcinoma $(<2 \%)$. Bladder lipoma is one of the mesenchymal tumours [1]. Its accurate prevalence is not really known, although it may be very low, since very few cases (13 to 16) have been reported in the literature so far; the age predilection is about 56.2 years [2,3].

The etiology -or risk factors- that may contribute to the development of this neoplasm is also unknown. Most of the cases are detected in the imaging techniques as incidental findings.

\section{Clinical \& Imaging findings:}

Bladder lipomas are usually asymptomatic. There are few cases reported in the literature describing bladder lipomas associated to some symptomatology (such as dysuria, macroscopic or microscopic haematuria, repetitive urinary tract infections or urinary incontinence). However, it was not completely demonstrated whether those signs and symptoms had been specifically caused by the lipoma itself $[2,3,4]$.

Just like all the lipomatous neoplasms that can develop in other locations, the bladder lipoma presents as a homogeneous lesion composed of macroscopic fat (thus showing density values between $-50 \mathrm{HU}$ and $-150 \mathrm{HU}$ on $\mathrm{CT}$, hyperintense on T1-weighted images on MRI and signal annulation on fatsuppressed sequences); other typical features may be its fusiform or oval shape and smooth margins $[2,3,4]$.

Regarding the ultrasonography, it is possible to suggest that it is a fat-constituted lesion, as it may show a hyperechogenicity much higher than the adjacent bladder wall $[2,4]$. However, this technique is not accurate enough to perform a proper diagnosis, as there is a considerable overlap between this entity and other benign and malign bladder neoplasms.

\section{Treatment \& Prognosis:}

At any rate, the presence -or absence- of symptomatology accompanying the tumour is not so relevant, because, once detected, a transurethral resection is indicated (since they are usually easily-accessible lesions at the cystoscopy), as wells as an anatomo-pathological examination, to clarify whether it is a benign lipoma or a well-differentiated liposarcoma.

After the resection, neither surgical-bed recurrences nor any other urinary tract locations have been reported in the literature.

\section{Differential Diagnosis:}

Other mesenchymal rare benign tumours that can arise from the submucosal layer of the urinary bladder include leiomyoma (the most frequent of them, 0.4\%), fibroma, plasmacytoma, hemangioma, neurofibroma and solitary fibrous tumour. Most of these neoplasms are almost indistinguishable between them, since they are usually asymptomatic incidental findings and they present as endophytic bladder nodules with smooth margins and homogeneous soft-tissue attenuation values.

Furthermore, these features may also be seen in smallsized or low-grade malignant neoplasms. Therefore, given the significantly high prevalence of the urothelial carcinoma, when a small intravesical lesion is detected on the ultrasound, the radiologist cannot be certain that it does not correspond to a malignant entity. A cystoscopy may be recommended, especially considering that the urothelial carcinoma can present as a multifocal disease.

When they grow, some of these entities are more distinguishable thanks to some specific features, such as hemangioma (presenting as a hypervascular mass), neurofibroma (diffuse, nodular bladder wall thickening with target sign on T2-weighted images, corresponding to lowsignal-intensity fibrosis surrounded by high-signal-intensity myxoid stroma), paraganglioma (ring calcification) or urachal 


\section{REFERENCES}

adenocarcinoma (midline, infraumbilical, soft-tissue mass with calcification, near the bladder dome).

Large malignant tumours may also show an aggressive behaviour, with heterogeneous enhancement (secondary to the presence of necrotic or cystic areas) and irregular-shaped margins that infiltrate the bladder wall. Although they can be asymptomatic, it is more likely that, in these cases, the patients suffer different symptoms, such as haematuria / microhaematuria, dysuria or urinary incontinence [5].

Paraganglioma is typically related to a clinical syndrome called micturition attack (catecholamine release during micturition, including hypertension, sweating, anxiety...).

Nevertheless, the bladder lipoma constitutes an important exception among the rest of entities arising from the bladder wall, as its fatty composition allows the radiologist to recognize it, as previously described. Only the liposarcoma could also show this feature, since they are also constituted by fat (especially well-differentiated liposarcomas, which usually show smooth margins). The less differentiated liposarcomas are, the easier is to recognize them as malignant neoplasms, since they tend to present more heterogeneous enhancement, irregular-shaped margins and infiltrative behaviour.

Finally, it is important to not confuse bladder lipomas with pelvic lipomatosis, an entity consisting in a nonmalignant overgrowth of homogeneous adipose tissue rounding the pelvic viscera. Sometimes, this tissue compresses the bladder, leading to images that can simulate fatty-lesions dependent of the bladder wall [6]. It can also compress the rest of the pelvic viscera, causing some symptoms such as dysuria, urinary incontinence or constipation. Nevertheless, a careful analysis of the CT or MRI images and appropriate multiplanar reconstructions may allow the radiologist to determine it is not a truly bladder lesion, but an extravesical disease.

\section{TEACHING POINT}

Bladder lipoma is a rare neoplasm that can be recognized as an endophytic fatty lesion arising from the bladder wall. The resection and anatomo-pathological examination is required in order to demonstrate it shows none histological signs of malignancy.
1. Wong-You-Cheong JJ, Woodward PJ, Manning MA, Davis CJ. From the archives of the AFIP: Inflammatory and nonneoplastic bladder masses: radiologic-pathologic correlation. Radiographics. 2006 Nov-Dec;26(6):1847-68. PMID: 17102055

2. Degheili JA, Bustros GD, El-Asmar JM, Nasr RW. A yellow-colored lipomatous lesion of the bladder: An unorthodox finding seen upon investigation for microscopic hematuria. Turk J Urol. 2018 Dec 19;45(5):389-392. PMID: 31509513

3. Gilbert B, Britcliffe A, Redwig F. Submucosal lipoma of the urinary bladder: Case report and systematic review. Urol Case Rep. 2018 Jun 22;20:54-56. PMID: 29988688

4. Val-Bernal JF, Azueta A, Ballestero R, Fuentes J, Fernández-Flórez A. Incidental bladder lipoma: a case report and review of the literature. Turk Patoloji Derg. 2015;31(1):64-7. PMID: 25371024

5. Federle MP, Brooke Jeffrey R, Woodward PJ, Borhani AA. Diagnostic Imaging - Abdomen. 2nd ed. Amirsys, 2011; IV-534-36. ISBN: 978-1-931884-71-6-2010.

6. Pereira JM, Sirlin CB, Pinto PS, Casola G. CT and MR imaging of extrahepatic fatty masses of the abdomen and pelvis: techniques, diagnosis, differential diagnosis, and pitfalls. Radiographics. 2005 Jan-Feb;25(1):69-85. PMID: 15653588

\section{FIGURES}

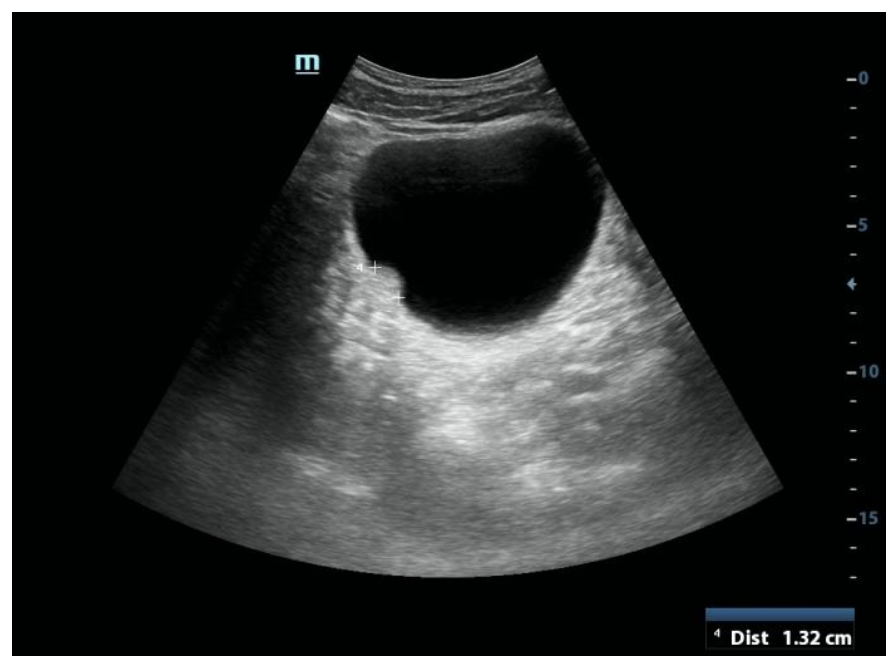

Figure 1: 63 year-old male with bladder lipoma.

FINDINGS: Incidental finding of a homogeneous hyperechoic lesion arising from the right bladder wall, with an endophytic growth. Notice that the echogenicity of the lesion is very similar to the fat around the bladder.

TECHNIQUE: Bladder ultrasound in axial-oblique plane, using C5-2 MHz convex probe. 

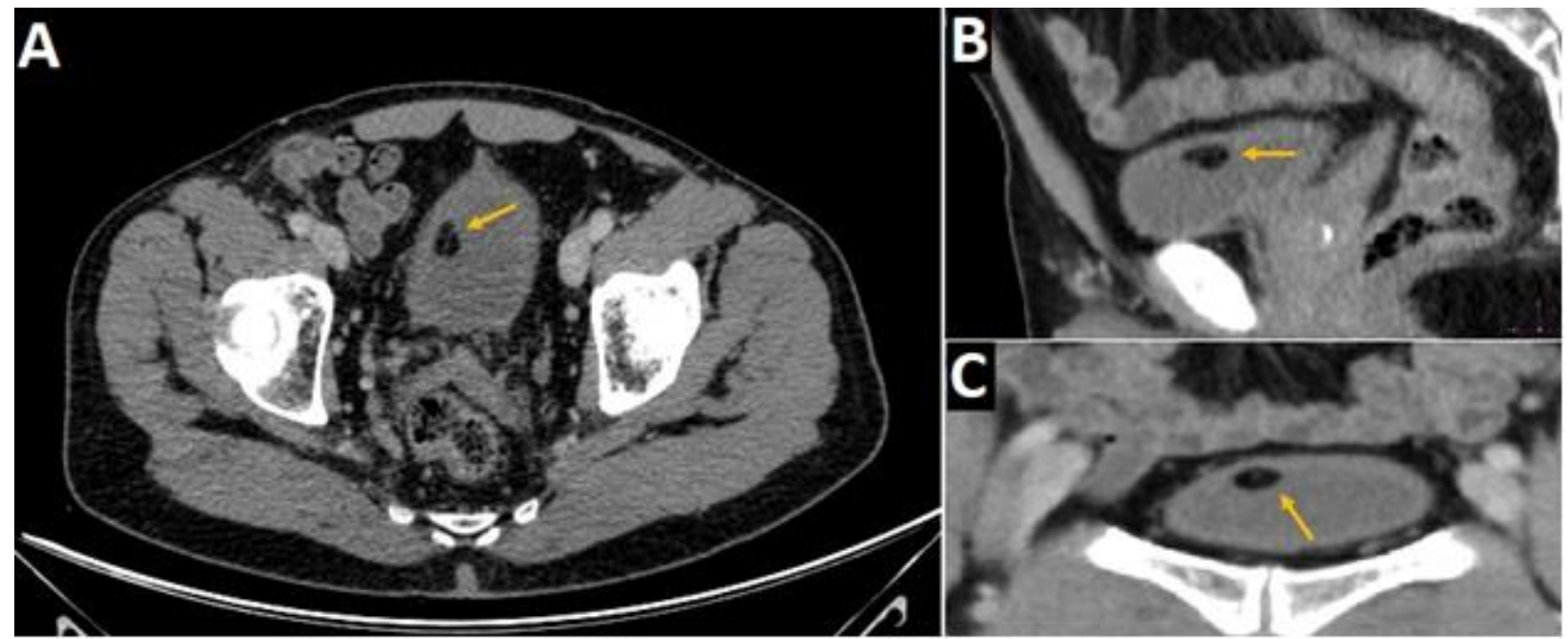

Figure 2: 63 year-old male with bladder lipoma.

FINDINGS: Contrast enhanced CT demonstrating the presence of a completely intravesical nodule (yellow arrows), dependent of the right-upper bladder wall. It looks like a homogeneously hypodense lesion, showing well-defined margins. It measured $1.8 \mathrm{x}$ $1.3 \times 0.9 \mathrm{~cm}$ (antero-posterior, transverse and cranio-caudal diameters, respectively).

TECHNIQUE: Contrast enhanced CT of the pelvis in the venous phase. Axial (A), sagittal (B) and coronal (C) planes (310 mAs; $120 \mathrm{Kv} ; 2 \mathrm{~mm}$ slice thickness; $1 \mathrm{~mm}$ slice space; $110 \mathrm{ml}$ iopamidol [300 mg/ml]).

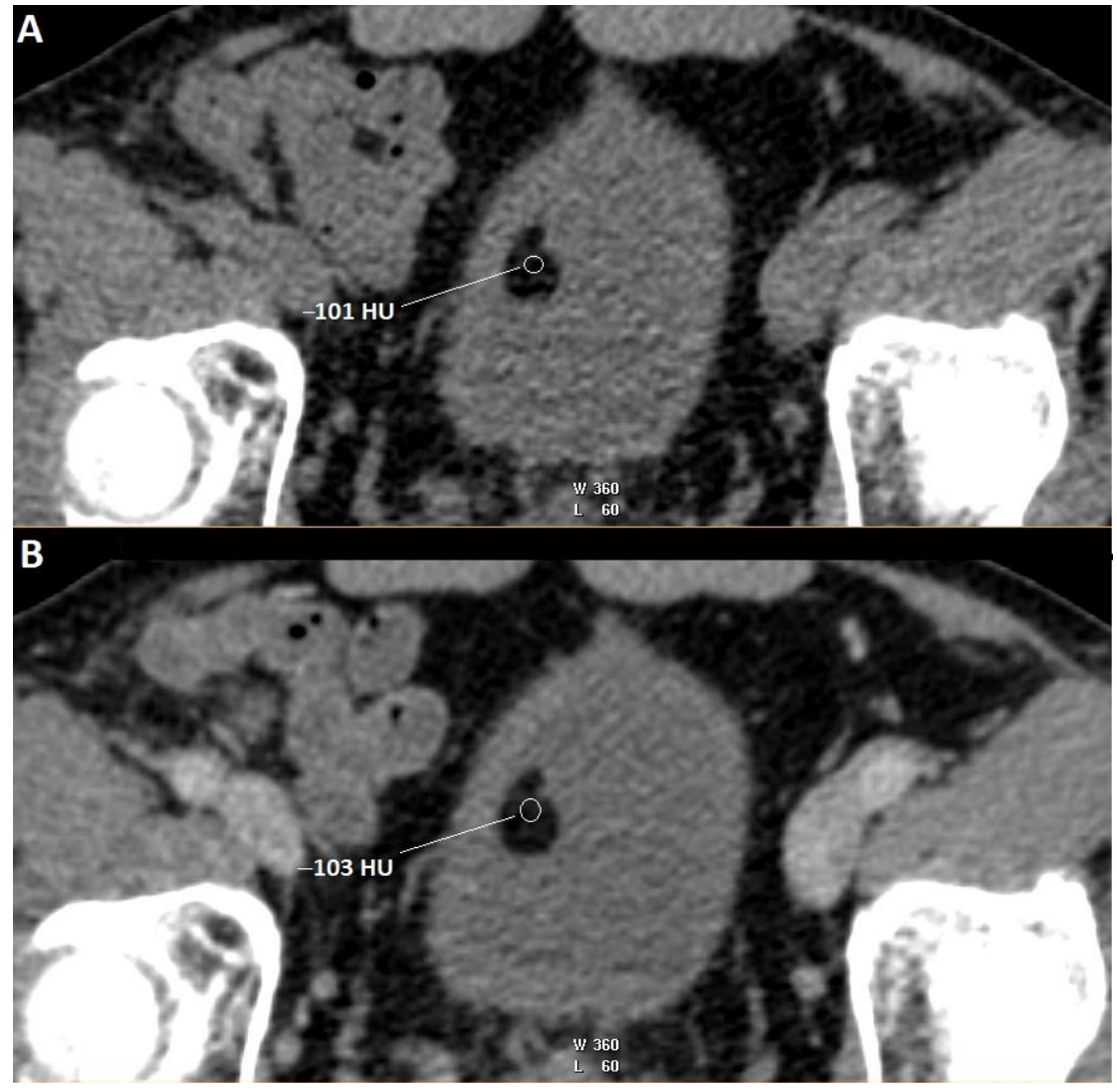

Figure 3: 63 year-old male with bladder lipoma.

FINDINGS: Non-enhanced CT (A) and contrast enhanced CT (B), where attenuation measurements indicate it is a fattycomposed lesion, without significant enhancement after iodine contrast administration.

TECHNIQUE: Axial non-enhanced CT of the pelvis (220 mAs; $120 \mathrm{Kv} ; 2 \mathrm{~mm}$ slice thickness; $1 \mathrm{~mm}$ slice space). (A) and axial contrast enhanced CT of the pelvis in the venous phase $(310 \mathrm{mAs} ; 120 \mathrm{Kv} ; 2 \mathrm{~mm}$ slice thickness; $1 \mathrm{~mm}$ slice space; $110 \mathrm{ml}$ iopamidol [300 mg/ml]). (B). 


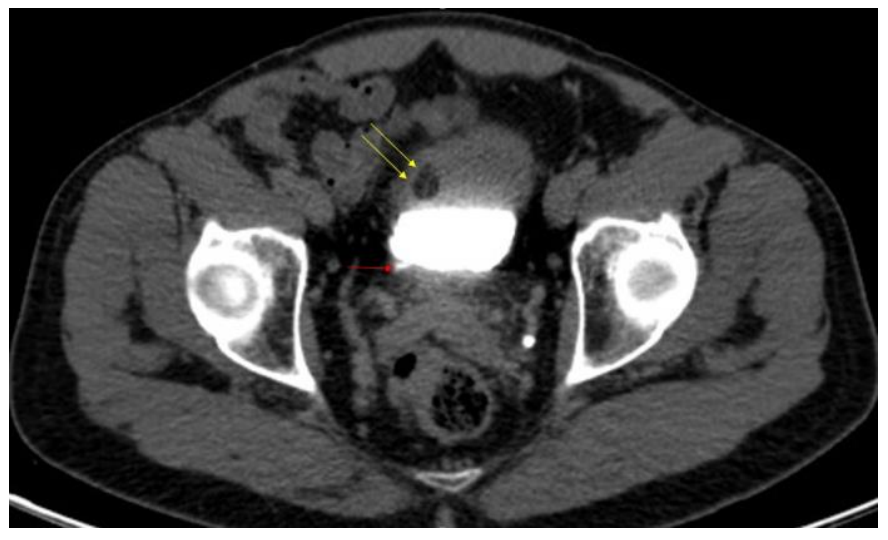

Figure 4: 63-year-old male with bladder lipoma.

FINDINGS: Excretory phase CT in axial plane, showing the distance between the neoplasm (yellow arrows) and the right ureterovesical junction (red arrow): $3 \mathrm{~cm}$ approximately.

TECHNIQUE: Axial contrast enhanced CT of the pelvis in the excretory phase $(310 \mathrm{mAs} ; 120 \mathrm{Kv} ; 2 \mathrm{~mm}$ slice thickness; 1 $\mathrm{mm}$ slice space; $110 \mathrm{ml}$ iopamidol [300 mg/ml]).

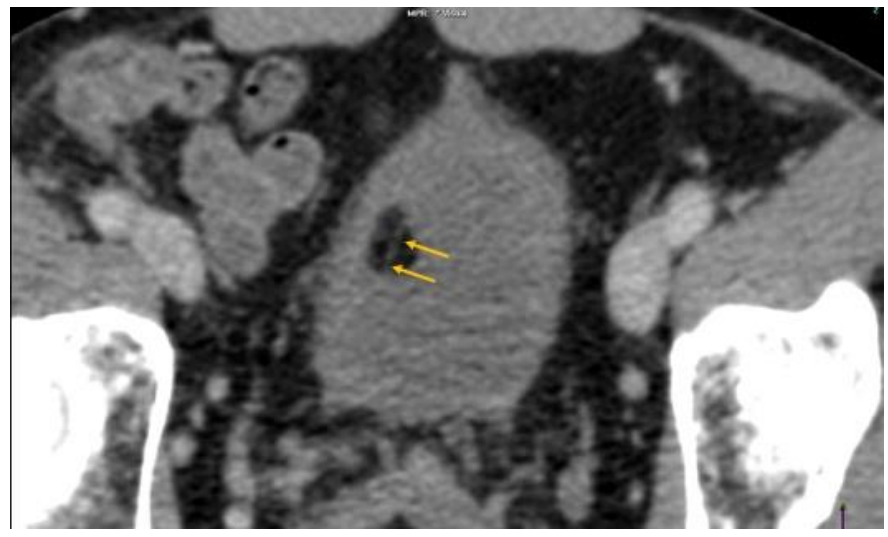

Figure 5: 63 year-old male with bladder lipoma.

FINDINGS: Axial contrast enhanced CT showing some hairline-thin septa inside the lesion (yellow arrows).

TECHNIQUE: Axial contrast enhanced CT of the pelvis in the venous phase $(310 \mathrm{mAs} ; 120 \mathrm{Kv} ; 2 \mathrm{~mm}$ slice thickness; $1 \mathrm{~mm}$ slice space; $110 \mathrm{ml}$ iopamidol [300 $\mathrm{mg} / \mathrm{ml}]$ ).
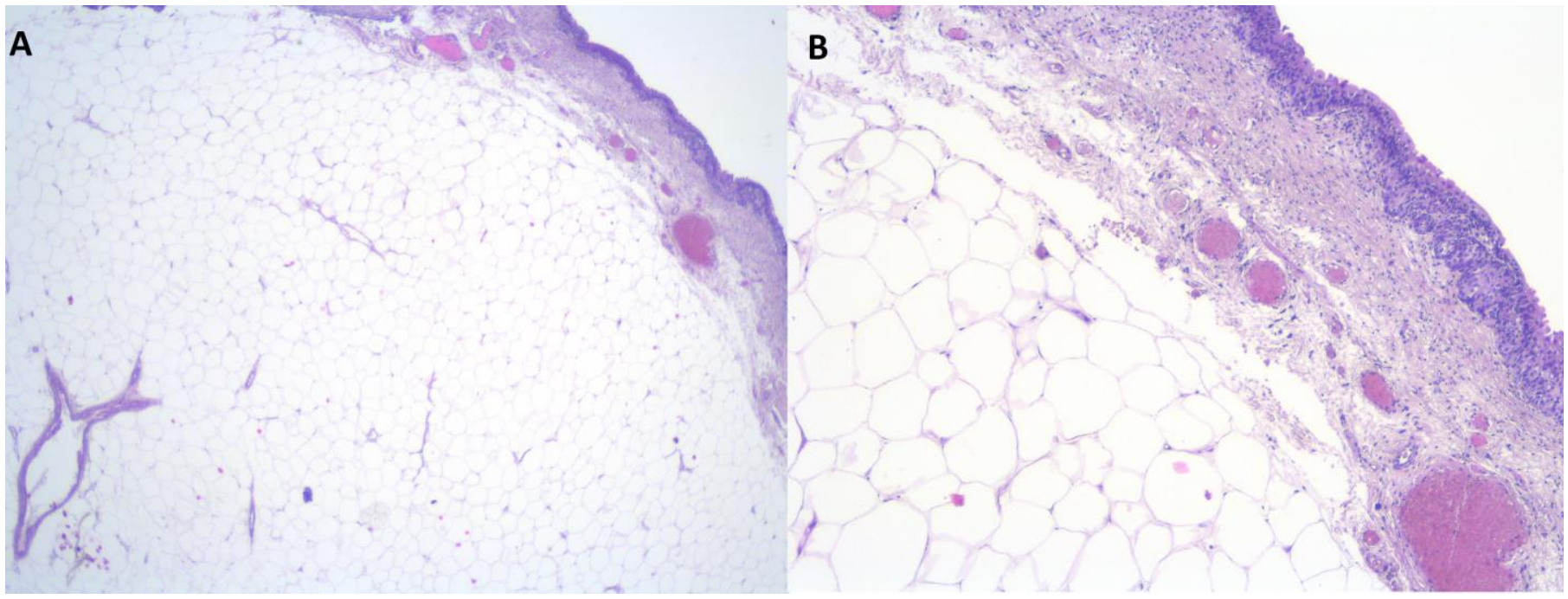

Figure 6: 63 year-old male with bladder lipoma.

Histopathology of the resected specimen $(\mathrm{H} \& \mathrm{E})(\mathrm{A})$, and magnified (B), demonstrating that the lesion is mostly composed of mature adipocytes.

\begin{tabular}{|l|l|}
\hline Etiology & Unknown. Incidental finding. \\
\hline Incidence & Very low. Only 13-16 cases reported in the literature \\
\hline Gender Ratio & No gender predilection \\
\hline Age Predilection & 56.2 years (SD: 12.4; range: 32-75 years) \\
\hline Risk factors & N / A \\
\hline Treatment & Transurethral resection \\
\hline Prognosis & Benign tumour. No recurrence described \\
\hline $\begin{array}{l}\text { Findings on } \\
\text { imaging }\end{array}$ & $\begin{array}{l}\text { - US: Well-defined hyperechoic endophytic bladder nodule } \\
\text { CTomogenous endophytic bladder nodule with fat density (between -50 HU and - }-150 \text { HU) } \\
\text { becomes hypointense on fat-suppressed sequences }\end{array}$ \\
\hline
\end{tabular}

Table 1: Summary table for bladder lipoma. 


\begin{tabular}{|c|c|c|c|c|c|}
\hline & Incidence & \begin{tabular}{|l|l|} 
Clinical \\
presentation
\end{tabular} & Imaging features (US) & Imaging features (CT) & Imaging features (MRI) \\
\hline \multirow[t]{2}{*}{$\begin{array}{l}\text { Bladder } \\
\text { lipoma }\end{array}$} & \multirow[t]{2}{*}{$\begin{array}{l}\text { Unknown. Very few } \\
\text { cases reported. }\end{array}$} & \multirow[t]{2}{*}{$\begin{array}{l}\text { Usually } \\
\text { asymptomatic. } \\
\text { Incidental finding. }\end{array}$} & $\begin{array}{l}\text { Fatty composition } \\
\text { (hyperechogenic). }\end{array}$ & \begin{tabular}{|l|} 
Fatty composition (thus \\
showing density values \\
between -50 HU and -150 \\
HU on CT).
\end{tabular} & $\begin{array}{l}\text { Fatty composition } \\
\text { (hyperintense on T1-weighted } \\
\text { images on MRI and signal } \\
\text { annulation on fat-suppressed } \\
\text { sequences). }\end{array}$ \\
\hline & & & \multicolumn{3}{|c|}{$\begin{array}{l}\text { Homogeneous. } \\
\text { Endophytic bladder nodule. } \\
\text { Smooth margins. } \\
\end{array}$} \\
\hline \multirow{3}{*}{$\begin{array}{l}\text { Other benign } \\
\text { mesenchymal } \\
\text { bladder } \\
\text { neoplasms }\end{array}$} & \multirow{3}{*}{$\begin{array}{l}\text { Mesenchymal } \\
\text { bladder neoplasms: } \\
5 \% \\
\text { Leiomyoma (most } \\
\text { common) }\end{array}$} & \multirow{3}{*}{$\begin{array}{l}\text { Usually } \\
\text { asymptomatic. } \\
\text { Incidental finding. }\end{array}$} & \multicolumn{3}{|l|}{$\begin{array}{l}\text { Endophytic bladder nodule. } \\
\text { Smooth margins. }\end{array}$} \\
\hline & & & $\begin{array}{l}\text { Hemangioma: } \\
\text { hypervascular mass } \\
\text { (detectable intralesional } \\
\text { flow on color-Doppler } \\
\text { images). }\end{array}$ & $\begin{array}{l}\text { Hemangioma: } \\
\text { hypervascular mass } \\
\text { (significant enhancement } \\
\text { after iodinated contrast } \\
\text { administration). } \\
\end{array}$ & $\begin{array}{l}\text { Hemangioma: hypervascular } \\
\text { mass (significant } \\
\text { enhancement after gadolinium } \\
\text { contrast administration). }\end{array}$ \\
\hline & & & & & $\begin{array}{l}\text { Neurofibroma: Diffuse, } \\
\text { nodular bladder wall } \\
\text { thickening with target sign on } \\
\text { T2-weighted images (low- } \\
\text { signal-intensity fibrosis } \\
\text { surrounded by high-signal- } \\
\text { intensity myxoid stroma) }\end{array}$ \\
\hline \multirow{4}{*}{$\begin{array}{l}\text { Malignant } \\
\text { mesenchymal } \\
\text { bladder } \\
\text { neoplasms }\end{array}$} & \multirow{4}{*}{$\begin{array}{l}\text { Mesenchymal } \\
\text { bladder neoplasms: } \\
5 \% \\
\text { Rhabdomyosarcoma } \\
\text { (most common in } \\
\text { children) } \\
\text { Leiomyosarcoma } \\
\begin{array}{l}\text { (most common in } \\
\text { adults) }\end{array}\end{array}$} & \multirow{4}{*}{$\begin{array}{l}\text { Haematuria / } \\
\text { microhaematuria. } \\
\text { Dysuria. } \\
\text { Urinary } \\
\text { incontinence. } \\
\text { Paraganglioma: } \\
\text { micturition attack (a } \\
\text { characteristic clinical } \\
\text { syndrome of } \\
\text { catecholamine } \\
\text { release during } \\
\text { micturition, } \\
\text { including } \\
\text { hypertension, } \\
\text { sweating, anxiety...) }\end{array}$} & \multicolumn{3}{|c|}{ Irregular-shaped / smooth margins. } \\
\hline & & & \multicolumn{3}{|c|}{ Small / Low-grade tumours: endophytic bladder nodule. } \\
\hline & & & $\begin{array}{l}\text { Large / Aggressive } \\
\text { tumours: solid mass that } \\
\text { infiltrates the walls of } \\
\text { the bladder }+/ \text { - } \\
\text { necrotic/cystic areas } \\
\text { (anechoic). }\end{array}$ & \begin{tabular}{|l|} 
Large / Aggressive \\
tumours: solid mass that \\
infiltrates the walls of the \\
bladder +/- necrotic/cystic \\
areas (hypodense).
\end{tabular} & $\begin{array}{l}\text { Large / Aggressive tumours: } \\
\text { solid mass that infiltrates the } \\
\text { walls of the bladder +/- } \\
\text { necrotic/cystic areas } \\
\text { (hyperintense on T2-weighted } \\
\text { sequences). }\end{array}$ \\
\hline & & & \begin{tabular}{|l|} 
Liposarcoma: \\
heterogeneous, partial \\
fatty composition \\
(hyperechogenic), \\
infiltrative behaviour. \\
\\
\end{tabular} & \begin{tabular}{|l|} 
Liposarcoma: \\
heterogeneous, partial \\
fatty composition (thus \\
showing density values \\
between -50 HU and - 150 \\
HU on CT), infiltrative \\
behaviour.
\end{tabular} & $\begin{array}{l}\text { Liposarcoma: heterogeneous, } \\
\text { partial fatty composition } \\
\text { (hyperintense on T1-weighted } \\
\text { images on MRI and signal } \\
\text { annulation on fat-suppressed } \\
\text { sequences), infiltrative } \\
\text { behaviour. }\end{array}$ \\
\hline \multirow{4}{*}{$\begin{array}{l}\text { Malignant } \\
\text { epithelial } \\
\text { bladder } \\
\text { neoplasms }\end{array}$} & \multirow{4}{*}{$\begin{array}{l}\text { Urothelial } \\
\text { carcinoma: } 90 \% \\
\text { Squamous cell } \\
\text { carcinoma: } 2 \%-8 \% \\
\text { Adenocarcinoma: } \\
<2 \%\end{array}$} & \multirow{4}{*}{$\begin{array}{l}\text { Haematuria / } \\
\text { microhaematuria. } \\
\text { Dysuria. } \\
\text { Urinary } \\
\text { incontinence. }\end{array}$} & \multirow{2}{*}{\multicolumn{3}{|c|}{$\begin{array}{l}\text { Irregular-shaped / smooth margins. } \\
\text { Uni / Multifocal. } \\
\text { Small / Low-grade tumours: endophytic bladder nodule. } \\
\end{array}$}} \\
\hline & & & & & \\
\hline & & & \begin{tabular}{|l|} 
Large / Aggressive \\
tumours: solid mass that \\
infiltrates the walls of \\
the bladder $+/-$ \\
necrotic/cystic areas \\
(anechoic). \\
\end{tabular} & \begin{tabular}{|l|} 
Large / Aggressive \\
tumours: solid mass that \\
infiltrates the walls of the \\
bladder +/- necrotic/cystic \\
areas (hypodense).
\end{tabular} & $\begin{array}{l}\text { Large / Aggressive tumours: } \\
\text { solid mass that infiltrates the } \\
\text { walls of the bladder +/- } \\
\text { necrotic/cystic areas } \\
\text { (hyperintense on T2-weighted } \\
\text { sequences). }\end{array}$ \\
\hline & & & \multicolumn{3}{|c|}{$\begin{array}{l}\text { Urachal adenocarcinoma: midline, infraumbilical, soft-tissue mass near the bladder } \\
\text { dome. }\end{array}$} \\
\hline \multirow{2}{*}{$\begin{array}{l}\text { Pelvic } \\
\text { lipomatosis }\end{array}$} & \multirow[t]{2}{*}{ Unknown } & \multirow[b]{2}{*}{$\begin{array}{l}\text { Secondary to } \\
\text { compression of the } \\
\text { pelvic viscera: } \\
\text { dysuria, urinary } \\
\text { incontinence, } \\
\text { constipation... } \\
\end{array}$} & \multicolumn{3}{|c|}{ Overgrowth of homogeneous adipose tissue rounding the pelvic viscera } \\
\hline & & & $\begin{array}{l}\text { Fatty composition } \\
\text { (hyperechogenic). }\end{array}$ & \begin{tabular}{|l|} 
Fatty composition (thus \\
showing density values \\
between -50 HU and -150 \\
HU on CT).
\end{tabular} & $\begin{array}{l}\text { Fatty composition } \\
\text { (hyperintense on T1-weighted } \\
\text { images on MRI and signal } \\
\text { annulation on fat-suppressed } \\
\text { sequences). }\end{array}$ \\
\hline
\end{tabular}

Table 2: Differential diagnosis table for bladder lipoma. 


\section{ABBREVIATIONS}

$\mathrm{CT}=$ Computed Tomography

$\mathrm{HU}=$ Hounsfield Units

MRI = Magnetic Resonance Imaging

US = Ultrasonography

\section{KEYWORDS}

Lipoma; bladder; mesenchymal bladder tumours; computed tomography; ultrasound

\section{Online access}

This publication is online available at:

www.radiologycases.com/index.php/radiologycases/article/view/3887

\section{Peer discussion}

Discuss this manuscript in our protected discussion forum at: www.radiolopolis.com/forums/JRCR

\section{Interactivity}

This publication is available as an interactive article with scroll, window/level, magnify and more features.

Available online at www.RadiologyCases.com

\section{Published by EduRad}

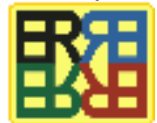

www.EduRad.org 